\title{
Oligochaete taxonomy - The rise of earthworm DNA barcode in India
}

\author{
H. Lalthanzara ${ }^{1 *}$, Ruth Lalfelpuii ${ }^{1}$, C. Zothansanga ${ }^{1}$, M. Vabeiryureilai ${ }^{2}$, \\ N. Senthil Kumar², G. Gurusubramanium ${ }^{3}$ \\ ${ }^{\mathrm{I}}$ Department of Zoology, Pachhunga University College, Aizawl 7960oI, India \\ ${ }^{2}$ Department of Biotechnology, ${ }^{3}$ Department of Zoology, Mizoram University, Tanhril 796004, India
}

Oligochaeta is a class of segmented worms under the phylum Annelida that are characterised by the presence of tiny setae in each body segment. Earthworms are the main members, consisting of approximately 6200 species. Their ecological importance is well known as they are the major soil macro-fauna; Aristotle had named them as "the intestines of soil". Classification of earthworms is a controversial issue since the introduction of modern taxonomical system on earthworm by Michaelsen in 1921. This is mainly because conventional identification using morphological and anatomical characters are complicated and confusing. The key diagnostic features such as the position and structure of the reproductive organs, clitellum and the associated tubercular pubertatis are not always reliable, particularly in different developmental stages, especially when the available specimens are the juveniles. DNA barcoding has offered a potential solution, even at the levels of identifying the juveniles or cocoons. Several genes including mitochondrial cytochrome-c oxidase I, 16S, 18S and 28S ribosomal RNAs, and protein-coding histone $\mathrm{H} 3$ genes have been introduced in the taxonomy and phylogeny of earthworm. It is anticipated that DNA barcoding will help conflicting taxonomy and further exploration of species diversity in India.

Received 01 December 2017 Accepted 14 December 2017

\section{*For correspondence $\bowtie$ :} hzara.puc@gmail.com

Key words: Oligochaeta; earthworm; DNA barcode; taxonomy.

\section{Introduction}

A class of annelids with segmented body that possess a simple tiny setae projecting from each segment such as earthworms are termed as Oligochaeta. Aquatic and terrestrial worms belong to Oligochaeta, and majority of the oligochaete taxa are earthworms. Based on ecological and taxonomical perspectives, earthworms are generally considered as a relatively well known group of soil invertebrates which constitutes the major soil macro-fauna. They drew scientific attention due to their ecological importance as major regulators of important soil processes, or because of their economic importance in agroecosystems. ${ }^{1,2}$

Darwin claimed that no living creatures had such a profound impact in the history of the world as has the earthworm. ${ }^{3}$ Being well known organisms during the ancient Greek and Egyptian, as they were able to dig and move in the soil while digesting it, Aristotle called them "the intestines of soil". 


\section{Historical Record}

From a taxonomical point of view, earthworms were mixed with all other worms and it is only in late $18^{\text {th }}$ century and the classifications by Lamarck separate annelids (segmented worms) from other worms. ${ }^{4}$ To date earthworm diversity described worldwide comprises of approximately 6200 earthworm species ${ }^{5}$, the first being Lumbricus terrestris by Carolus Linnaeus in $1758 .^{6}$

A brief history of the oligochaete taxonomy was presented by Csuzdi and Szlávecz ${ }^{6}$, and according to them, there were only 70 new species descriptions published in the first century of earthworm taxonomy (1758-1865), the situation significantly improved by the 1860 s when a new generation of zoologists began exploring this important soil engineer worms. Research by Johan Gustaf Hjalmar Kinberg (1820-1908), Edmond Perrier (1844-1921), Gustav Eisen (18471940), Rutgerus Horst (1849-1930), László Örley (1856-1887), Daniel Rosa (1857-1944) and Frank Evers Beddard (1858-1925) greatly enriched the knowledge of earthworm systematics. ${ }^{6}$ Johann Wilhelm Michaelsen (1860-1937), Sir Walter Baldwin Spencer (1860-1929), Sir William Blaxland Benham (1860-1950) and Luigi Cognetti De Martiis (1878-1931) make fundamental contributions to earthworm taxonomy. ${ }^{6}$ Csuzdi and Szlávecz (2016) called the period 1886-1905 as "the golden age" of earthworm taxonomy because of the enormous and significant contributions made by Örley (1885), Benham (1886), Beddard (1895), Rosa (1893, 1895) and Michaelsen $(1900,1903)^{6}$

After the outbreak of the World War I, Stephenson had contributed immense taxonomic information of Oligochaeta in his books - The Fauna of British India (1923) and The Oligochaeta (1930). The majority of earthworm systematics available was perhaps the outcome of his work. Gordon Enoch Gates (1897-1987), Lev Černosvitov (1902-1945) and Grace Evelyn Pickford (1902-1986) added Michaelsen and Stephenson's taxonomic work. ${ }^{6}$ Later, after the World War II, the dwindling oligochaete taxonomic interest was revived by Kenneth Ernest
Lee (1927-2007), Pietro Omodeo (1919-) and Barrie Gillean Molyneux Jamieson (1934-). Danuta Jadwiga Plisko (1927-), Reginald William Sims (1926-2012), Marcel Bouché and Gilberto Righi (1937-1999), András Zicsi (1928-2015) and others had performed their earthworm identification works. ${ }^{6}$ Many other workers from different parts of the globe had contributed a lot since last few decades. In Indian subcontinent, J.M. Julka is serving as the sole earthworm taxonomists since 1980 's till date. In addition to this, R. Paliwal and other did some works in the field of earthworm's morpho-anatomical taxonomy mainly based on monographs. All these highly skilled efforts are based on morphological and anatomical investigation, which is known as "conventional method of identification".

\section{The Taxonomic Impediment}

Regarding the classification of earthworms, there is controversy over the view of different scientists. Some scientists have developed their own classification schemes which have been further revised and developed over years. Basis of modern taxonomical system on earthworm was formed by Michaelsen (1921). ${ }^{6}$ Later, Stephenson (1930) simplified Michaelsen's classification of earthworms into fourteen families. The classification of the family megascolecidae has been more controversial as Omodeo (1958), Gates (1959) and Lee (1959) independently proposed their own classification. Later Sims $^{7}$ investigated with computer techniques, and follow Gates classification of megascolecidae. In order to study the biological as well as the ecological process of earthworm, a correct species diagnosis is vital.

Traditional method of identification deals with morphological as well as anatomical characters, such as the position of spermathecal pore, first dorsal pore, arrangement of setae, shape and segments covered by clitellum, position and shape of female and male pore, penial setae and genital markings are of taxonomic importance in its morphology. The chief anatomical features of systematic importance includes the gizzard, calciferous glands, the seg- 
ment in which the intestine begins, presence and position of intestinal caeca, typhlosole, the details of vascular systems, nephridia, sex organs like testes, spermathecae, seminal vesicles, prostate glands, ovary, oviduct and ovisac. All these characters were considered while identifying earthworm species. But still the key characters considered for correct taxonomic identification differs from species to species.

However, conventional identification using morphological and anatomical characters are complicated as this method requires minute and detail examinations of external morphology as well as internal anatomy of adults, which necessitates the engagement of expert taxonomists. This method is time consuming and very laborious work, thus it is considered cumbersome. Furthermore, identification is limited to sexually mature specimen as the key character in species diagnosis involves the position and structure of the reproductive organs, clitellum and the associated tubercular pubertatis. ${ }^{8,9}$ As a result, identification of juveniles of closely related species (e.g. members of the genus Lumbricus) is not feasible in most cases such that soil invertebrate taxonomic studies are greatly hampered as only generic identifications for juveniles are available for species richness evaluation. ${ }^{10}$ In addition, diverge taxonomic system can results between researchers where they use different criteria or sections of the earthworm for identification since, the degree of variability of many morphological and anatomical characteristics of earthworms can differ and features can overlap between taxa. ${ }^{11}$ For instance since 1913 till date, a good number of re-description of earthworm species have been recorded for a number of taxa. ${ }^{12-25}$

Many described species of earthworm comprising several distinct genetic lineages were hypothesized to represent cryptic species, the distinction of which is difficult if not impossible on a morphological basis has been revealed by the use of molecular approaches in biodiversity research, thus, suggesting that traditional morphological identification might be inaccurate. Taking into consideration for cryptic diversity has profound implications for earthworm taxon- omy. For instance, Bouche and Beugnot (1972) ${ }^{26}$ described the two morphs of Lumbricus terrestris which later was observed that these two morphs are in fact two distinct species which were both formally named but considered as synonyms for a long period, the large body-sized L. terrestris sensu stricto and the smaller $\mathrm{L}$. herculeus (Savigny). ${ }^{27}$ The existence of at least five different cryptic species in Hormogastridae Hormogaster elisae was also reported. ${ }^{28}$ Extensive analysis of 457 sequences, representing 49 genera within 8 families, a very high level of potential cryptic diversity, with about 1 for 6 identified species having one or more divisions exceeding $10 \%$ divergence was observed by Rougerie et al. ${ }^{29}$. It is thus obvious that there are some limitations with conventional morpho-anatomical identification, particularly between intra-specific variations.

\section{Modern Molecular Approach}

The modern molecular approach- DNA based species identification can provide solution for such taxonomic impediment by providing a highly reliable automated identification tool usable for any life stages and on any kind of tissue fragments. Indeed, reliable identifications of juvenile specimens ${ }^{29-31}$ which conventional morpho-anatomical identification cannot accomplish.

DNA barcoding, a means of species identification is a technique in biodiversity research ${ }^{32}$ which uses information i.e, a standardized region of DNA common across all taxa, by DNA sequencing under universal condition. This gene region constitutes a small part $(<1000 \mathrm{bp})$ of the genome and can be easily obtained. These features leads to standardization across species and laboratories, thus providing a platform for global exchange of homologous data and capitalizing on the efforts of others to build a more flexible system. ${ }^{33}$ For DNA barcoding of animals, the Mitochondrial DNA (mtDNA) which uses 658 $\mathrm{bp}$ fragments of the mitochondrial cytochrome-c oxidase I CO1 gene can be used as a standard DNA tag to identify individuals belonging to the same species, as well as to distinguish between 
individuals from different species and identification for phylogenetic studies of the animal kingdom.

This has turned out to be exceedingly useful in tracing evolutionary history ${ }^{34}$ as it is present in all eukaryotic organisms, and are maternally inherited, and most of the nucleotide substitutions occur at neutral sites, evolves much more rapidly as compared to nuclear DNA thereby resulting in the accumulation of differences between closely related species. ${ }^{35-37}$ Nuclear and mitochondrial genomes exhibit different patterns of inheritance. ${ }^{38}$

In a more advance level, coX 1 sequence data have been used to study the intra and inter -phylogenetic relationships. Relative homogeneity is maintained by concerted evolution, where mutations rapidly spread to all members of the gene family even if there are arrays located on different chromosomes. ${ }^{39-41}$ The DNA barcodes based species or lineage discrimination is congruent in many cases with those obtained with other molecular markers. For instance, result obtained from AFLP is in congruent with COI for Great Britain Lumbricidae, microsatellites support the integrity of most COI lineages described by King et al. $^{42}$ for Allolobophora chlorotica (Savigny). ${ }^{43}$ A high congruence between COI lineages and those obtained with $16 \mathrm{~S}$ t-RNAs and 28S within the morphologically similar species Hormogaster elisae (Álvarez) was also documented by Novo et al. ${ }^{28}$ Tree-based taxon clustering as well as statistical taxon separation analysis indicates that molecular evidence does coincide with morphological hypotheses. ${ }^{44}$ Hence, species identification based on DNA sequence analysis proved to be feasible for the analysed taxa.

\section{DNA Barcoding for Earthworm Species Characterization}

Use of DNA barcoding for identification of earthworm species is improving our capability in describing juveniles or cocoons into oligochaete biodiversity study. Similarly, molecular identification will enable the use of damaged or broken specimens for identification which otherwise present inadequate observable characters for conventional identification. Relatively few molecular analysis tools have been developed for earthworms, despite the economic and ecological importance of these soil ecosystem engineers. ${ }^{45}$ Several genes such as mitochondrial cytochrome-c oxidase I, COI ${ }^{10,11,46-57} ; 18 \mathrm{~S}$ ribosomal RNA ${ }^{11,48,57-59} ; 28$ S ribosomal RNA ${ }^{51,54,56,58 ;}$; $16 \mathrm{~S}$ ribosomal DNA ${ }^{11,48,49,51,54-57,59}$ and protein-coding histone $\mathrm{H} 3$ genes ${ }^{54,56}$ have been recently used for studying the taxonomy and phylogeny of earthworm species. Loongyai et al. ${ }^{60}$ have obtained partial sequences for ribosomal 16S rDNA and subunit one for mitochondrial cytochrome c oxidase (COI) of four earthworm species and reported that result of sequence analysis combined with taxonomic characters could distinguish the different species of earthworm. First overview of DNA barcoding approach for discrimination, identification of new taxa, and species identification of juveniles and detection of cryptic diversity for earthworm species was provided by Rougerie et al. ${ }^{29} \mathrm{~A}$ number of studies have been published which highlight the potential of DNA barcoding in opening new avenues in the field of earthworm ecology, phylogeography and population genetics. ${ }^{47,61,62}$

As compared to morphological taxonomy, DNA barcoding provides more rapid progress on species identification. ${ }^{63}$ It can sustain decisions taken for nomenclatural acts (alpha taxonomy) including descriptions of new taxa, synonymies or rehabilitation of synonymized species names. The method, alone or as a complement with new generation environmental sequencing, also represents a promising tool for biodiversity assessment from local to global scales, or for studying the biogeography and population genetics of specific species or lineages. ${ }^{64}$ Adopting DNA barcoding is enhancing the accuracy of earthworm studies and more generally benefit the community of soil biologists. Thus, recently many papers has been published and new earthworm species have been described with the help of DNA barcoding. ${ }^{52-58,65-73}$

Once DNA barcodes have unveiled putative cases of cryptic diversity, morphological features needs to be re-evaluated for species discrimina- 
tion. ${ }^{27}$ Recent studies suggest that characters which have long been considered as uninformative for species discrimination and description might be far more informative than previously assumed due to DNA barcoding. ${ }^{46,62,74,75}$ There are reports that taxonomists scrutinize the DNA barcoding analyses results, using them when relevant within the traditional workflow of new species descriptions and taxonomic revisions ${ }^{76-80}$ thus, enabling reliable identification.

DNA barcoding have been supported by different national and international initiatives, of which the International Barcode of Life project (iBOL, http://ibol.org/) is the most determined one in term of investment. The sequences generated are collectively compiled in the Barcode of Life Data System (BOLD, http://www.barcodinglife.org), a central integrative bioinformatics platform, which serves as a scientific workbench supporting all phases of the analytical pathway from specimen collection to tightly validated barcode library. ${ }^{81}$ A specific "Barcoding Earthworms" campaign (EarthwormBOL) which assembles libraries of DNA barcodes from samples collected all over the world was launched. To date, the earthworm reference library contains more than 18000 sequences for over 1200 species from more than 49 different countries; these numbers are expected to rise quickly within the next few years ${ }^{82}$ Barcode data can also be used as a support or additional evidence in the description of new species to avoid taxonomic confusion. ${ }^{62}$

\section{Earthworm Species Diversity and DNA Barcoding - Indian Scenario}

India is one of the important megabiodiverse countries. It harbours about $11 \%$ of global earthworm diversity which includes about 509 species placed in 10 families and 69 genera. ${ }^{83}$ No information was available from India on molecular characterization and diversity of earthworm species till 2008. ${ }^{84}$ However, Meenatchi ${ }^{85}$, Giraddi et al. ${ }^{86}$ and Meenatchi et al. ${ }^{87}$ used RAPD-PCR method for the first time to assess the genetic diversity of Indian earthworms. Other preliminary works includes Kumar et al. ${ }^{65}$
Mathur et al. ${ }^{88}$ Sharma et al. ${ }^{89}$ and Biruntha et al. ${ }^{90}$ Various molecular markers are being used such as Random Amplified Polymorphic DNA (RAPD), Restriction Fragment Length Polymorphism (RFLP) and Simple Sequence Repeat (SSR) ) $9,91,92^{2}$ which have profound use in genetic diversity estimation..$^{93}$ Rao et al..$^{58}$ has performed phylogenetic analysis and multiple sequence alignment of Eudrilus eugeniae 18S rRNA and observed a pattern of variations among different species. Kushwaha et al. ${ }^{94}$ published their modified protocol for earthworm DNA extraction. Jaya et al. ${ }^{66}$ have sequenced the mitochondrial CO1 gene of six species of earthworms and observed that the cytochrome-c oxidase I (CO1) exhibited a unique barcode to a particular species. Earthworm DNA barcoding work in India is at its initial stage, such that very little information is available. Recently, a project on diversity studies of Indian earthworms using DNA barcodes has been initiated by Shweta Yadav. A total of 801 of Indian earthworm DNA sequence have been made available in the Boldsystem such as Acanthodrilidae 4, Almidae 3, Eudrilidae 22, Hormogastridae 7, Lumbricidae 6, Megascolecidae 426, Moniligastridae 122, Octochaetidae 199, Rhinodrilidae $6 .^{82}$ This represents only a small portion of Indian earthworms and therefore further challenges remain open for the enthusiast biologists to undertake research in the field of molecular approach, the DNA barcoding for earthworm species identification. The most recent description (2017) of new earthworm species from India, the discovery of two new Moniligastrids species viz. Drawida polydiverticulata sp. nov. and Drawida thomasi sp. nov. are not provided with molecular data. ${ }^{95}$

Further scientific investigations on earthworm diversity and alpha taxonomy are, therefore, required and it is imperative to make an attempt conducting an investigation on earthworm species and genetic diversity available in different unexplored soil habitat conditions of India, particularly of north-east India as it lies within the Himalaya and Indo-Myanmar biodioversity hotspots. The most reliable identification of earthworm taxa is now based on the combination of the conventional morpho-anatomical 
characters and molecular characters (DNA barcode), therefore further exploration of species diversity and genetic diversity as well as phylogenetic analysis of earthworms Indo-Myanmar and Indo-China of northeast India has been initiated by the authors. This will enrich the knowledge of earthworm diversity of India and the world by providing fundamental information on biodiversity and molecular phylogenetic data of earthworms of north east India.

\section{References}

I. Lavelle, P. \& Spain, A.V. (200I). Soil Ecology. Kluwer Academic Publishers, Dordrecht.

2. Decaens, T., Jimenez, J.J., Gioia, C., Measey, G.J. \& Lavelle, P. (2006). The values of soil animals for conservation biology. European Journal of Soil Biology 42, S23$\mathrm{S}_{3} 8$.

3. Yeates, G. (20I7). Earthworms. Te Ara - the Encyclopedia of New Zealand, http://www.TeAra.govt.nz/en/ earthworms.

4. Blanchart, E., Brauman, A., Brossard, M., Duboisset, A. \& Feller, C. (2010). Historical approach of the role of earthworms and termites in soil functioning. $19^{\text {th }}$ World Congress of Soil Science, Soil Solutions for a Changing World I - 6 August 2oro, Brisbane, Australia.

5. Csuzdi, C.S. (20I2): Earthworm species, a searchable database. Opuscula Zoologica (Budapest) 43(I), 97-99.

6. Csuzdi, C. \& Szlávecz, K. (2016). Earthworm (Clitellata: Megadrili) taxonomy in the last 200 years: A homage to András Zicsi (1928-2015). Opuscula Zoologica (Budapest) 47, OI-07.

7. Edwards, C.A. \& Lofty, J.R. (1977). The Biology of Eartbworms. Chapman and Hall, London, U.K. pp. 42SI.

8. Bouche, M. (1972). Lombriciens de France. Ecologie et Syste'matique, Institut National de Recherches Agronomiques, Paris.

9. Sims, R.W. \& Gerard, B.M. (1999). Earthworms. FSC Publications, London, UK.

Io. Richard, B., Decaens, T., Rougerie, R., James, S.W., Porco, D. \& Hebert, P.D.N. (2010). Re-integrating earthworm juveniles into soil biodiversity studies: species identification through DNA barcoding. Molecular Ecological Resource Io, 606-6I4.

II. Pop, A.A., Wink, M. \& Pop, V.V. (2003). Use of I8S, I6S rDNA and cytochrome c oxidase sequences in earth- worm taxonomy (Oligochaeta, Lumbricidae). Pedobiologia $47,428-433$.

I2. Michaelsen, W. (1913) Oligochäten vom tropischen und südlich-subtropischen Afrika I. Zoologica Stuttgart 26, 139-170

13. Pickford, G.E. (1937). A Monograph of the Acanthodriline Earthworms of South Africa, Heffer, Cambridge. 6I2 $\mathrm{p}$.

14. Murchie, W.R. (1959). Redescription of Allolobophora muldali Omodco. Obio Journal of Science, 59, 229-232.

I5. Jamieson, B.G.M. (197I). A review of the Megascolecoid earthworm genera (Oligochaeta) of Australia. Part I. Reclassification and Checklist of the megascolecoid genera of the world. Proc. R. Soc. Qld. 82, 75-86.

I6. Jamieson, B.G.M. (1972). The Australian earthworm genus Spenceriella and description of two new genera (Megascolecidae: Oligochaeta). Mem. Natn. Mus. Viet. 33, $73-87$

17. Zicsi A. (198I) Weitere Angaben zur Lumbricidenfauna Italiens (Oligochaeta: Lumbricidae) Opusc. Zool. Budapest, $\mathbf{1 7} / \mathbf{1 8}$, 157-180.

18. Coates, K.A. (1990). Redescription of Aspidodrilus and Pelmatodrilus enchytraeids (Annelida, Oligochaeta) ectocommensal on earthworms. Canadian Journal of Zoology, 68, 498-505.

19. Blakemore, R.J. (1997). Two new genera and some new species of Australian earthworms (Acanthodrilidae, Megascolecidae: Oligochaeta). Journal of Natural History 31,1785-1848.

20. Blakemore, R.J. (20II). Further records on non-cryptic New Zealand earthworms. Zookeys. 160, 23-46.

2I. Blakemore, R.J. (2012). On Schmarda's lost earthworm and some newly found New Zealand species (Oligochaeta: Megadrilacea: Lumbricidae, Acanthodrilidae, Octochaetidae, \& Megascolecidae s. stricto), Journal of Species Research, I, I05-I32.

22. Shen, Huei-Ping, Tsai, Chu-Fa \& Tsai, Su-Chen. (2003). Six new earthworms of the genus Amynthas (Oligochaeta: Megascolecidae) from Central Taiwan. Zoological Studies 42, 479-490.

23. Plisko, J.D. (2007). New species of South African acanthodriline earthworms of the genera Eodriloides and Chilota, with a redescription of Chilota quindecimus (Oligochaeta: Acanthodrilidae). African Invertebrates 48, 33-40.

24. Bantaowong, U., Chanabun, R., Piyoros Tongkerd, P., Sutchari,t.C, James, S.W. \& Panha, S. (2OII). New earthworm species of the genus Amynthas Kinberg, 1867 
from Thailand (Clitellata, Oligochaeta, Megascolecidae). ZooKeys 90, 35-62

25. Chanabun, R., Sutcharit, C., Tongkerd, P. \& Panha, S. (2013). The semi-aquatic freshwater earthworms of the genus Glyphidrilus Horst, I889 from Thailand (Oligochaeta, Almidae) with re-descriptions of several species. ZooKeys 265, I-76.

26. Bouche, M.B., \& Beugnot, M. (1972). La Complexité taxonomique de Lumbricus Herculeus illustrée par les caractéristiques de populations de stations de la R.C. P. 40. Revue d'Écologie et de Biologie Du Sol, 9, 697-704.

27. James, S.W., Porco, D., Decaens, T., Richard, B., Rougerie, R. \& Erseus, C. (2010). DNA barcoding reveals cryptic diversity in Lumbricus terrestris L., 1758 (Clitellata): resurrection of L. herculeus (Savigny, I826). PLOS ONE s, eI5629.

28. Novo, M., Almodovar, A., Fernandez, R., Trigo, D. \& Cosin, D.J. (2010). Cryptic speciation of hormogastrid earthworms revealed by mitochondrial and nuclear data. Molecular Phylogenetics and Evolution 56, 507-512.

29. Rougerie, R., Decaens, T., Deharveng, L., Porco, D., James, S.W., Chang, C.H., Richard, B., Potapov, M., Suhardjono, Y. \& Hebert, P.D.N. (2009). DNA barcodes for soil Animal taxonomy. Pesquisa Agropecuária Brasileira 44, 789-80I.

30. Palumbi, S.R. \& Cipriano, F. (1998). Species identification using genetic tools: the value of nuclear and mitochondrial gene sequences in whale conservation. Journal of Heredity 89, 459-464.

31. Symondson, W.O.C. (2002). Molecular identification of prey in predator diets. Molecular Ecology II, 627-64I.

32. Hebert, P.D.N., Cywinska, A., Ball, S.L. \& deWaard, J.R. (2003a). Biological identifications through DNA barcodes. Proceedings of Royal Society of London: B Biological Science 270, 313-321.

33. Armstrong, K.F. \& Ball, S.L. (2005). DNA barcodes for biosecurity: Invasive species identification. Philosophical Transactions of the Royal Society B: Biological Science 360, I813-1823.

34. Hebert, P.D.N., Ratnasingham, S. \& dewaard, J.R. (2003b). Barcoding animal life: cytochrome c oxidase I divergences among closely related species. Proceedings of Royal Society of London: B Biological Science 270, S596S599.

35. Brown, W.M., George, M.J. \& Wilson, A.C. (1979). Rapid evolution of animal mitochondrial DNA. Proceedings of National Academy of Science 76, 1967-1971.

36. Moore, W.S. (1995). Inferring phylogenies from
mtDNA variation: mitochondrial gene trees versus nuclear gene trees. Evolution 49, 718-726.

37. Mindell, D.P., Sorenson, M.D., Huddleston, C., Miranda, H.C. \& Knight, A. (1997). Phylogenetic relationships among and within select avian orders based on mitochondrial DNA. In: Avian Molecular Evolutionary Systematics. (Mindell, D.P. Ed.), New York, Academic Press, pp. 214-2I7.

38. Behura, S.K. (2006). Molecular marker systems in insects: current trends and future avenues. Molecular Ecology 15, 3087-3113.

39. Arnheim, N. (1983). Concerted evolution of multigene families. In: Evolution of genes and proteins (M. Nei and Koehn RK, eds). Sinauer, Sunderland, Mass, pp. 38-6I.

40. Gerbi, S.A. (1985). Evolution of ribosomal DNA. In: Molecular Evolution and Genetics (R. J. Macintyre, ed.) pp. 419-5I7.

4I. Tautz, D., Arctander, P., Minelli, A., Thomas, R.H. \& Vogler, A.P. (2003). A plea for DNA taxonomy. Trends in Ecological ES Evolution 18, 70-74.

42. King, R.A.,Tibble, A.L. \& Symondson, W.O.C. (2008). Opening a can of worms: unprecedented sympatric cryptic diversity within British lumbricid earthworms. Molecular Ecology 17, 4684-4698.

43. Dupont, L., Lazrek, F., Porco, D., King, R.A., Rougerie, R., Symondson, W.O.C., Livet, A., Richard, B., Decaens, T., Butt, K.R. \& Mathieu, J. (2OII). New insight into the genetic structure of the Allolobophora chlorotica aggregate in Europe using microsatellite and mitochondrial data. Pedobiologia 54, 217-224.

44. Jalali, S.K., Ojha, R. \& Venkatesan, T. (2015). DNA Barcoding for Identification of Agriculturally Important Insects. New In: Horizons in Insect Science: Towards Sustainable Pest Management (Chakravarthy, A.K. ed.). Springer India.

45. Kautenburger, R. (2006). Genetic structure among earthworms (Lumbricus terrestris L.) from different sampling sites in western Germany based on random amplified polymorphic DNA. Pedobiologia 5o, 257-266.

46. Chang, C.H., Lin, Y.H., Chen, I.H., Chuang, S.C. \& Chen, J.H. (2007). Taxonomic re-evaluation of the Taiwanese montane earthworm Amynthas wulinensis Tsai, Shen and Tsai, 200I (Oligochaeta: Megascolecidae): polytypic species or species complex? Organism Diversity and Evolution 7, 231-240.

47. Huang, J., Xu, Q., Sun, Z.J., Tang, G.L. \& Su, Z.Y. (2007). Identifying earthworms through DNA barcodes. Pedobiologia 51, 30I-309.

48. Pop, A.A., Cech, G., Wink, M., Csuzdi, C. \& Pop, V.V. 
(2007). Application of I6S, I8S rDNA and COI sequences in the molecular systematics of the earthworm family Lumbricidae (Annelida, Oligochaeta). European Journal of Soil Biology 43, 43-52.

49. Briones, M.J.I., Moran, P. \& Posada, D. (2009). Are the sexual, somatic and genetic characters enough to solve nomenclatural problems in lumbricid taxonomy? Soil Biology and Biochemistry 4I, 2257-227I.

5o. Otomo, P.V., Vuuren, B.J.V. \& Reinecke, S.A. (2009). Usefulness of DNA barcoding in ecotoxicological investigations: resolving taxonomic uncertainties using Eisenia Malm 1877 as an example. Bulletin of Environmental Contamination and Toxicology 82, 26I-264.

5I. Losada, M.P., Ricoy, M., Marshall, J.C. \& Domnguez, J. (2009). Phylogenetic assessment of the earthworm Aporrectodea caliginosa species complex (Oligochaeta: Lumbricidae) based on mitochondrial and nuclear DNA sequences. Molecular Phylogenetics and Evolution 52, 293-302.

52. Blakemore, R.J. (2013) Earthworms newly from Mongolia (Oligochaeta, Lumbricidae, Eisenia). ZooKeys 285, I2I.

53. Blakemore, R.J., Lee, S., Lee, W. \& Seo, H-Y. (2013) Two new Korean earthworms (Annelida, Oligochaeta, Megadrilacea, Megascolecidae). ZooKeys 307, 35-44.

54. Cosín, D.J.D., Novo, M., Fernández, R., Marchán, D.F. \& Gutiérrez, M. (2014). A new earthworm species within a controversial genus: Eiseniona gerardoi sp. n. (Annelida, Lumbricidae) - description based on morphological and molecular data. ZooKeys 399, 7I-87.

55. Zhao, Q., Cluzeau, D., Jiang, J., Petit, E.J. \& Briard, C. (2015). Molecular Phylogeny of Pheretimoid Earthworms (Haplotaxina: Megascolecidae) Based on Mitochondrial DNA in Hainan Island, China. Molecolar Biology 4, 138 .

56. Aspe, N.M., Kajihara, H. \& James, S.W. (2016). A molecular phylogenetic study of pheretimoid species (Megascolecidae) in Mindanao and associated islands, Philippines. European Journal of Soil Biology 73, II9-I25.

57. Csuzdi, C., Chang, C-H., PavlōÂcek, T., Szederjesi, T., Esopi, D. \& SzlaÂvecz. K. (2017). Molecular phylogeny and systematics of native North American lumbricid earthworms (Clitellata: Megadrili). PLoS ONE I2, eor81504.

58. Rao, R.K., Laxmi C. Mushan, L.C. \& Shaikh, S.A. (20I4). Molecular Phylogenetic Study of Earthworm Eudrilus engeniae. International Journal of Advanced Biotechnology and Research 5, 202-207.
59. Kim, Y-N., Dickinson, N., Bowie, M., Robinson, B., \& Boyer, S. (2017). Molecular identification and distribution of native and exotic earthworms in New Zealand human-modified soils. New Zealand Journal of Ecology 4I, 2I8-225.

6o. Loongyai, W., Bangrak, P. \& Chantsavang, S. (20II). External Morphological Comparison, Taxonomic Revision and Molecular Differentiation of the Four Economically Important Species of Earthworm in Thailand. International Journal of Agriculture and Biology 13, 553558.

6I. Chang, C.H., Rougerie, R. \& Chen, J.H. (2009). Identifying Earthworms through DNA barcodes: pitfalls and promise. Pedobiologia 52, I7I-I80.

62. Chang, C.H. \& James, S. (20II). A Critique of earthworm molecular phylogenetics. Pedobiology 54, $\mathrm{S}_{3}-\mathrm{S}_{9}$.

63. Gregory, T.R. (2005). DNA barcoding does not compete with taxonomy. Nature 434,I067.

64. Decaens, T., Porcoa, D., Rougeriea, R., Brown, G.G. \& James, S.W. (2013). Potential of DNA barcoding for earthworm research in taxonomy and ecology. Applied Soil Ecology 65, 35-42.

65. Kumar, K.S., Kumar, U.S. \& Neelanarayanan, P. (2013). Mitochondrial I6s RNA sequence for earthworm identification from semi evergreen forest type of Puliyancholai reserved forest in Kolli Hill, Tamil Nadu, South India. Journal of Microbiology and Biotechnology Research 3, 40-45.

66. Jaya, M., Aja, M. \& Nair, V.K. (2015). Biomolecular Approach to Oligochaete Taxonomy. International Journal of New Technologies in Science and Engineering 2, 74-83.

67. Nguyen, A.D. \& Nguyen, T.T. (2015) Notes on Metaphire multitheca (Chen, 1938) (Oligochaeta, Megascolecidae) recorded from Vietnam, with descriptions of two new species. ZooKeys 506, 127-136.

68. Novo, M., Marta Novo, Fernández, R., Sónia C.S., Andrade, Marchán, D.F., Cunha, L., Darío J. \& Díaz Cosín, D.J. (2015). Phylogenomic analyses of a Mediterranean earthworm family (Annelida: Hormogastridae). Molecular Phylogenetics and Evolution 94b, 473-478.

69. Shen, H-P., chih-han Chang, C-H., \& Chih, W-J. (2015). Earthworms from Matsu, Taiwan with descriptions of new species of the genera Amynthas (Oligochaeta: Megascolecidae) and Drawida (Oligochaeta: Moniligastridae). Zootaxa 3973, 425-450.

7o. Decaens, T., Porco, D., James, S.W., Brown, G.G., Chassany, V., Dubs, F., Dupont, L., Lapied, E., Rougerie, R., Rossi, J.P. \& Roy, V. (2016). DNA bar- 
coding reveals diversity patterns of earthworm communities in remote tropical forests of French Guiana, Soil Biology \& B Biochemistry 92, 171-183.

71. Paoletti, M.G., Blakemore, R.J., Csuzdi, C., Dorigo, L., Dreon, A.L. \& Gavinelli, F. (2016) Barcoding Eophila crodabepis sp. nov. (Annelida, Oligochaeta, Lumbricidae), a Large Stripy Earthworm from Alpine Foothills of Northeastern Italy Similar to Eophila tellinii (Rosa, I888). PLoS ONE II, eoI51799.

72. Razafindrakoto, M., Csuzdi, C. James, S.W. \& Blanchart, E. (2016). New earthworms from Madagascar with key to the Kynotus species (Oligochaeta: Kynotidae). Zoologischer Anzeiger 268, I26-135.

73. Sun, J., James, S.W., Jiang, J., Yao, B., Zhang, L., Liu, M., Qiu, J. \& Hu, F. (2017). Phylogenetic evaluation of Amynthas earthworms from South China reveals the initial ancestral state of spermathecae, Molecular Pbylogenetics and Evolution II5,IO6-II4

74. Chang, C.H. \& Chen, J.H. (2005). Taxonomic status and intraspecific phylogeography of Two sibling Species of Metaphire (Oligochaeta: Megascolecidae) in Taiwan. Pedobiologia 49, 591-6oo.

75. Lowe, C.N. \& Butt, K.R. (2008). Allolobophora chlorotica (Savigny, 1826): evidence for classification as two separate species. Pedobiologia 52, 8I-84.

76. Decaens, T. \& Rougerie, R. (2008). Descriptions of two new species of Hemileucinae (Lepidoptera: Saturniidae) from the region of Muzo in Colombia-evidence from Morphology and DNA barcodes. Zootaxa, 1944, 34-52.

77. Fisher, B.L. \& Smith, M.A. (2008). A revision of Malagasy species of Anochetus Mayr and Odontomachus Latreille (Hymenoptera: Formicidae). PLoS ONE 3, eI787.

78. Vaglia, T., Haxaire, J., Kitching, I.J., Meusnier, I. \& Rougerie, R. (2008). Morphology and DNA barcoding reveal three cryptic species within the Xylophanes neoptolemus and loelia species-groups (Lepidoptera: Sphingidae). Zootaxa 1923, I8-36.

79. Porco, D., Bedos, A. \& Deharveng, L. (2010). Description and DNA barcoding assessment of the new Species Deutonura gibbosa (Collembola: Neanuridae: Neanurinae), a common Springtail of Alps and Jura. Zootaxa 2639, 59-68.

8o. Stoev, P., Akkari, N., Zapparoli, M., Porco, D., Enghof, H., Edgecombe, G,D., Georgiev, T. \& Penev, L. (2010). The centipede Genus Eupolybothrus verboeff, 1907 (Chilopoda: Lithobiomorpha: Lithobiidae) in North Africa, A cybertaxonomic revision, with a key to all species in the genus and the first use of DNA barcoding for the group. ZooKeys so, 29-77.

8I. Ratnasingham, S. \& Hebert, P.D.N. (2007). Barcoding Bold: The Barcode of Life Data System (www.barcodinglife.org). Molecular Ecology Notes 7, 355 -364 .

82. Boldsystem http://www.boldsystems.org/index.php/ Taxbrowser_Taxonpage?taxid $=25192$ (Io ${ }^{\text {th }}$ October 2017).

83. Verma, D., Bharti, S. \& Yadav, S. (2010). Earthworm resources in the Gangetic plain of Uttar Pradesh, India. International Journal of Biodiversity and Conservation 2, I34-I39.

84. Giraddi, R.S., Kale, R.D. \& Biradar, D.P. (20I4). Earthworms and organic matter recycling- an overview from Indian perspective. Karnataka Journal of Agricultural Science 27(3), 273-284.

85. Meenatchi, R. (2008). Molecular Characterization of Earthworms, Nutrient Assessment and Use of Vermitechnologies in Pest Management. Ph.D. Thesis, University of Agricultural Science, Dharwad (Karnataka).

86. Giraddi, R.S., Meenatchi, R., Suresh, B., Biradar, M.D. \& Biradar, D.P. (2009). Standardization of method for genomic DNA extraction in earthworms. Karnataka Journal of Agricultural Science 22, 918-920.

87. Meenatchi, R., Giraddi, R.S. \& Biradar, D.P. (2009). Assessment of genetic variability among strains of earthworm, Eudrilus engeniae (Kinberg) using PCR-RAPD technique. Karnataka Journal of Agricultural Science 22, 942-945.

88. Mathur, A., Bhat, R., Verma, S.K., Prakash, A., Prasad, G.B.K.S. \& Dua, V.K. (2010). Standardization of method for Genomic DNA extraction in Eudrilus engeniae. The Indian Pharmacists 9, 49-5I.

89. Sharma, A., Sonah, H., Deshmukh, R.K., Gupta, N.K., Singh, N.K., \& Sharma, T.R. (20II). Analysis of Genetic Diversity in Earthworms using DNA Markers. Zoological Science 28, 25-31.

9o. Biruntha, M., Paula, J.A., \& Mariappan, P. (2013). Vermicultural and molecular characterization of composting endemic earthworms American Journal of Research Communication I, 168-I80.

91. Fang, D. (1997). Identification of closely related cultivars with inter simple sequence report markers. Theoretical Applied Genetics 95, 408-419.

92. Yadav, S. \& Mullah, M. (2017). A Review on Molecular Markers as Tools to Study Earthworm Diversity. International Journal of Pure and Applied Zoology 5, 62-69.

93. Agarwal, R.K., Brar, D.S., Nandi, S., Huang, N. \& 
Kailash, G.S. (1999). Phylogenitic relationships among Oryza sp. revealed by molecular markers. Theoretical Applied Genetics 98, 1320-1328.

94. Kushwaha, T., Vishwakarma, A., Paliwal, R., Burla, S. \& Yadav, S. (2015). A Simple Protocol to extract DNA from earthworm tissue for Molecular studies. Research \& Reviews: Journal of Zoological Sciences 4, 33-37.

95. Narayanan, S.P., Sathrumithra, S., Christopher, G. \&
Julka, J.M. (2017). New species and new records of earthworms of the genus Drawida from Kerala part of the Western Ghats biodiversity hotspot, India (Oligochaeta, Moniligastridae). ZooKeys 69I, I-I8. 